\title{
LEGAL REGULATION OF RELIGIOUS CLOTHING IN THE PUBLIC SPHERE IN THE CZECH REPUBLIC IN LIGHT OF THE CASE OF A MUSLIM STUDENT VERSUS A SECONDARY SCHOOL
}

\section{Damián NĚMEC ${ }^{1}$}

This study examines the issue of religious clothing in public spaces in the Czech Republic. It describes the legal regulation/restriction of this exercise of religious freedom in three areas: photographs on personal documents, face coverings at public assemblies, and religious clothes worn in schools. Regarding the third area, it examines in detail a Muslim student's case against a medical secondary school. This case shows that the wearing of religious clothing is very loosely regulated in the Czech Republic and is restricted to a few specific areas.

\begin{tabular}{l|l} 
basic human rights \\
freedom of religion \\
fing \\
freedom of assembly \\
school \\
religious clothing
\end{tabular}

\section{Introduction}

Part of the freedom of religion is in its external expression, including the use of religious clothing in public. This study aims to describe and evaluate the legal regulation of the use of religious clothing in public in the Czech Republic based on national legislation and case law. It aims to lay the foundation for further elaborations of this topic, especially through comparisons with both the legal regulations of other states and the judicial decisions of the European Union. This rather narrow treatment is chosen in order to provide a useful elaboration of this topic across a relatively wide historical breadth, starting with the establishment of the Czechoslovak Republic in 1918, and to maintain a tolerable scope.

1 | Professor and Chairman, Department of Church History and Church Law, Sts. Cyril and Methodius School of Theology, Palacký University in Olomouc, damian.nemec@upol.cz. 
In the first chapter, we describe the general historical background of legal regulation in the territory occupied by the Czech Republic since the inception of Czechoslovakia in 1918. The second chapter presents the constitutional basis of the right to express one's religion by wearing religious clothing. In the next two chapters, we discuss the regulation/ restriction of the exercise of this right in the field of personal documents and the rights of participants in public assemblies, which are regulated by law. ${ }^{2}$ In the last chapter, we address the wearing of religious clothing in schools, and discuss the case of a lawsuit launched by a Muslim student against a medical secondary school. In addition to describing legal regulations regarding the public wearing of religious clothing, we also evaluate them and discuss their prospects in terms of de lege ferenda.

\section{General historical background of legal regulation}

After its inception, the Czechoslovak Republic embarked on a path of legal continuity. The Austrian legal order continued to apply in Czech lands (the territory occupied by the present Czech Republic), while the Hungarian legal system applied in Slovakia (the territory of the present Slovak Republic) and, with modifications, in Carpathian Ruthenia, which was ceded to the Soviet Union in June 1945. Both legal systems contained a large number of regulations in the area of religious law, which continued to apply in Czechoslovakia.

The establishment of the communist regime in Czechoslovakia in February 1948 led to a redefinition of church-political relations and, thus, of religious law. After the end of the negotiation phase (especially with the Roman Catholic Church) in 1949, the regime unilaterally introduced substantial legal changes. The adoption of the Act on the Economic Indemnity of Churches and Religious Societies in October 1949 was of fundamental importance, as it established a path of legal discontinuity. The repealing provision in $\S 14$ briefly stipulates: 'All regulations governing the legal relations of churches and religious communities are repealed'.

This established a legal vacuum in several areas, which was filled by administrative will, which was often arbitrary, aimed at building a socialist society as set out in the introductory sentence of the Declaration at the very beginning of the Czechoslovak Constitution of May 1948: ' We, the Czechoslovak people, declare that we are firmly intent to build our liberated state as a people's democracy that will ensure a peaceful path to socialism'.

The path to socialism under the leadership of the Communist Party of Czechoslovakia, confirmed by the Czechoslovak Constitution of 1960, ${ }^{4}$ became the starting point not only for administrative practice, but also for new 'socialist' legislation. The Education Act (also called the 'Act on Unified School') is particularly important in terms of religious symbols and clothing, as it completely nationalised education in Czechoslovakia and pushed the religious element out of it, except for a severely limited teaching of religion. ${ }^{5}$ However, the

2| We deliberately avoid the issue of ordered uniforms (e.g. in the army, police, fire brigades).

3 | Constitutional act no. 150/1948 Sb., Constitution of the Czechoslovak Republic.

4 | Constitutional act no. 100/1960 Sb., Constitution of the Czechoslovak Socialist Republic.

5 | Act no. 95/1948 Sb., on the basic regulation of unified education (School Act). 
regime also violated its own laws, as the Communist Party's instructions superseded the legal order. This was acknowledged retrospectively by the parliament of the independent Czech Republic. ${ }^{6}$ Religious life was also pushed out of the public sphere from 1948 to 1989. Its public expression was minimally tolerated and was restricted without necessarily being regulated by law.

After the overthrow of the Communist Party of Czechoslovakia in 1989/1990, the state was democratised. This was manifested by both new guarantees of human and civil rights and efforts to minimise interference with these rights by laws and bylaws. The consequence was a tempering or even absence of legal regulation, which was reflected in the issue of religious clothing in the public sphere.

\section{Constitutional basis of the expression of freedom of religion}

Czechoslovakia's constitutional basis was laid by the 1991 Charter of Fundamental Rights and Freedoms. ${ }^{7}$ Article 15 of the Charter enshrines the guarantee of freedom of thought and conscience, scientific research, and the creation of art (forum internum):

(1) Freedom of thought, conscience, and religious convictions are guaranteed. Everyone has the right to change their religion or faith, or be non-denominational.

(2) Freedom of scholarly research and artistic creation is guaranteed.

(3) No one may be compelled to perform military service if this is contrary to their conscience or religious convictions; detailed provisions are laid down in law.

Article 16 strongly guarantees both individual and corporate expressions of religious convictions (forum externum):

(1) Everyone has the right to freely manifest their religion or faith, either alone or in community with others, in private or public, through worship, teaching, practice, and observance.

(2) Churches and religious societies govern their own affairs; in particular, they establish their own bodies and appoint their clergy, as well as found religious orders and other church institutions, independent of state authorities.

(3) The conditions under which religious instruction may be provided at state schools should be set by law.

(4) The exercise of these rights may be limited by law in the case of measures necessary in a democratic society for the protection of public safety and order, health and morals, or the rights and freedoms of others.

The right to assemble is guaranteed in the same way:

(1) The right to a peaceful assembly is guaranteed.

6 | Act no. 198/1993 Sb., on the illegality of the communist regime and on resistance against it. 7 | Constitutional act no. 23/1991 Sb., which introduces the Charter of Fundamental Rights and Freedoms as a constitutional law of the Federal Assembly of the Czech and Slovak Federal Republic. 
(2) The exercise of this right may be limited by law in the case of assemblies held in public places if it concerns measures that are necessary in a democratic society for the protection of the rights and freedoms of others, public order, health, morals, property, or the security of the state. However, an assembly shall not be made to depend on a grant of permission by a public administrative authority.

The 1991 Charter continued to play a very important role in the case law of the Constitutional Court. The Czech Republic's constitution does not regulate human and civil rights, but refers to the Charter, ${ }^{8}$ re-adopted as part of the constitutional order of the Czech Republic. ${ }^{9}$

A representative commentary on the Charter states that, in light of the case law of the European Court of Human Rights, it is concluded that the wearing of religious symbols and clothing is understood as a limitable expression of religious beliefs rather than as part of an individual's religious freedom. At the same time, it is not only the formal aspect that is decisive, but also the intention. For example, a headscarf is not a religious symbol as such, but it becomes a manifestation of religious belief if a Muslim woman wears it specifically in a stable form. In the same way, religious symbols can consist of a specific arrangement of an exterior (e.g. religious or clerical clothing, clerical collar, hijab, niqab, burkas, beard, yarmulke, uncut hair, kirpan). However, the specific limits of the application of this fundamental right must be understood in the light of the cultural and social context of a given state. In the Czech Republic, the context is that of a cooperative model of the relationship between the state and churches/religious communities ('CRC' hereafter). ${ }^{10}$

A special act on CRCs was adopted in $1991 .{ }^{11}$ The law was rather short and favourable to CRC activities. The 2002 Act on Churches and Religious Communities ${ }^{12}$ excluded the public activities of CRCs from its scope, thus leaving it competent to deal only with purely internal religious activities. However, the intervention of the Constitutional Court in November 2002 renewed the legal recognition of the broad activities of CRCs. ${ }^{13}$

Neither of these laws specifically regulates the expression of religious belief through the regulation of religious clothing. Therefore, because of their development, both laws maintain a guarantee of the freedom of expression of religious belief in accordance with the Charter of Fundamental Rights and Freedoms.

8 | Constitutional act no. 1/1993 Sb., Constitution of the Czech Republic.

9 | Resolution of the Presidency of the Czech National Council no. 2/1993 Sb., on the promulgation of the Charter of Fundamental Rights and Freedoms as part of the constitutional order of the Czech Republic.

10 | Jäger, 2012a, p. 380; Jäger, 2012b, pp. 397-398, 416.

11 | Act no. 308/1991 Sb., Act on Churches and Religious Communities.

12 | Act no. 3/2002 Sb., Act on Churches and Religious Communities.

13 | Judgment of the Constitutional Court of 27 November 2002 no. 4/2003 Sb. in the matter of a proposal to repeal act no. 3/2002 Sb., on freedom of religion and the status of Churches and religious Communities and to amend certain acts (Act on Churches and Religious Communities), or to repeal certain provisions of this Act. 


\section{Requirements for photographs on ID cards and passports}

\section{| 3.1. Overview of legal regulation regarding identity cards}

The legal regulation of identity cards began in the interwar period (the period of the First Czechoslovak Republic). The first Czechoslovak legal norm was a government decree of August 8,1919, which introduced general citizenship cards for citizens of the Czechoslovak Republic. This regulation followed Imperial Regulation no. 31/1857 RGBl, on the introduction of a new passport system, ${ }^{14}$ and its execution instruction no. 32/1857 RGBl. ${ }^{15}$ The general citizenship card took the form of a small-format workbook (of approximately A6 size), the data of which were entered manually. The card included a verbal description of the citizen's appearance because it did not contain a photograph. However, the card was not a compulsory identity document, but was specified as optional in national communication. ${ }^{16}$ This decree left the determination of the date of effectiveness in the territories of Czechoslovakia up to the Minister of the Interior. The Minister set the effectiveness date for Bohemia, Moravia, and Silesia (i.e. for the territory of the present-day Czech Republic) as May 1, 1920.17 Therefore, none of these decrees contained regulations for taking photographs for general citizenship cards.

After Czechoslovakia was occupied by the Nazi regime (on March 15, 1939), a decree of the Reich Protector Konstantin von Neurath of March 17, 1939, introduced a mandatory general citizenship card for citizens of the Protectorate of Bohemia and Moravia following the German model, the so-called Kennkarte, which included a photograph for the first time. ${ }^{18} \mathrm{~A}$ decree of President of the Republic Edvard Beneš, issued in exile in London in 1944 , laid down the rule of legal discontinuity for protectorate legal acts, ${ }^{19}$ so this regulation expired on May 5, 1945. ${ }^{20}$

Two fundamental changes occurred in 1948, during the communist regime: The current general citizenship card was renamed the 'identity card', but it was introduced on January 1, 1949, and made compulsory only for persons in the border zone. ${ }^{21}$ This act was repealed by a government decree on identity cards of 1953, which stipulated the obligation to have an identity card for all citizens over the age of $15 .{ }^{22}$ Decree no. 2384/1948 Ú.l. I

14 | Kaiserliche Verordnung Nr. 31/1857 RGBl., wirksam für alle Kronländer, über die Einführung eines neuen Paßsystemes.

15 | Verordnung der Ministerien des Äußern des Innern und des Handels Nr. 32/1857 RGBl., der obersten Polizeibehörde und des Armee-Ober-Commando, wirksam für alle Kronländer, womit neue paßpolizeiliche Vorschriften erlassen werden.

16 | Regulation of the Government of the Czechoslovak Republic no. 481/1919 Sb. z. a n., which introduces general citizenship cards.

17 | Decree of the Minister of the Interior no. 338/1920 Sb. z. a n., on when the Order of the Government of the Czechoslovak Republic of 8 August 1919, no. 481 Sb. z. a n., on general civil identification cards, comes into force.

18 | Všeobecné občanské legitimace [General citizenship cards]. Available at: http://www.scanzen. cz/dobove-dokumenty/prukazy/vseobecna-obcanska-legitimace.

19 | Constitutional Decree of the President of the Republic no. 11/1944 Úř. věst. čsl., on the restoration of legal order.

20 | Government regulation no. 31/1945 Sb. z. a n., which stipulates the end of the unfree period for the field of regulations on the restoration of the legal order.

21 | Act no. 198/1948 Sb., on identity cards.

22 | Government regulation no. 61/1953 Sb. on identity cards. 
of the Ministry of the Interior implemented regulations for the Act. It prescribes as follows with regard to photography: ${ }^{23}$ two photos measuring $5.5 \times 6.5 \mathrm{~cm}$, showing the applicant's head (uncovered) in a half-profile measuring at least $2 \times 3 \mathrm{~cm}$.

The requirements for the photograph were changed slightly by a 1953 decree of the Ministry of National Security, ${ }^{24}$ which prescribes as follows: two non-retouched $5.5 \mathrm{~cm} \mathrm{x}$ $6.5 \mathrm{~cm}$ photos, with a $1.5 \mathrm{~cm}$ wide white border.

Minor changes, especially regarding identity cards' period of validity, were introduced by the Identity Cards Act in $1957 .{ }^{25}$ The 1958 Implementing Decree did not make any changes to the design of the photograph.

The Identity Card Act of 1957 was in force until the end of 1999, although it was amended several times. Two decrees were issued to implement this act by the end of 1989 , in $1978^{26}$ and in $1984 .{ }^{27}$ The requirements they set for making a photograph are almost identical. We quote from § 2 (2) para. (b) of the 1984 Decree:

two sharp, non-retouched photographs taken from the same negative on a smooth, glossy halfcardboard or taken by a multi-lens instrument, measuring $3.5 \times 4.5 \mathrm{~cm}$, showing the citizen in a three-quarter profile, in civic clothing, without headgear and spectacles with dark glasses, the height of the facial part of the head (from the eyes to the chin) at least $13 \mathrm{~mm}$.

After the change in political conditions and the disintegration of Czechoslovakia (on January 1, 1993), another decree was issued in 1993 for the same 1957 act. ${ }^{28}$ Identity cards were now laminated, so the scope of the information they contain has radically decreased. Photo requirements have been slightly modified. They are as follows: two sharp, unretouched, non-toned, black and white photographs measuring $5.5 \times 6.5 \mathrm{~cm}$, with a $1.5 \mathrm{~cm}$ wide white border depicting the citizen in a three-quarter profile, in civilian clothing and without headgear (head size approximately $3 \mathrm{~cm}$ ), and without spectacles with dark lenses, paper surface smooth, matte.

The first 'post-November' law on identity cards was issued in 1999, made effective from July 1, 2000. ${ }^{29}$ This introduced many changes. It transfers responsibility for identity cards from the Police of the Czech Republic to district authorities. ${ }^{30}$ It introduces the registration of identity cards via computer technology connected with the basic inhabitants register and other components of the information system covering the registration of

23 | Decree of the Ministry of the Interior no. 2384/1948 Ú. 1. I, which sets out the details for identity cards.

24 | Decree of the Ministry of National Security no. 240/1953 Ú. l., which issues more detailed regulations on identity cards.

25 | Act no. 75/1957 Sb. on identity cards.

26 | Decree of the Federal Ministry of the Interior no. 135/1978 Sb., which issues more detailed regulations on identity cards.

27 | Decree of the Federal Ministry of the Interior no. 119/1984 Sb., which issues more detailed regulations on identity cards.

28 | Decree of the Ministry of the Interior no. 128/1993 Sb., which implements the act on identity cards.

29 | Act no. 328/1999 Sb. on identity cards.

30 | As of January 1, 2003, with the entry into force of act no. 320/2002 Sb., on the amendment and repeal of certain acts in connection with the termination of district offices, this agenda passed from the extinct district offices to the municipal offices of municipalities with extended powers; cf. Říha, 2013, p. 21. 
inhabitants, making it possible to use ID cards as travel documents (instead of passports). Therefore, it aims to unify the legal regulation of identity cards with legislation governing the registration of inhabitants, travel documents, and registries. Concerning the exercise of religious freedom in the context of the Charter of Fundamental Rights and Freedoms, the act lays down restrictions on the use of religious clothing, especially headgear, by the requirement to submit the following: one photograph measuring $35 \times 45 \mathrm{~mm}$, corresponding to the current fashion of the citizen, shown in front view with the height of the facial part of the head from the eyes to the chin of at least $13 \mathrm{~mm}$, in civilian clothes, without dark glasses (except for the blind), and without headgear, unless its use is justified on religious or medical grounds; in such a case, the headgear must not cover the facial area in a way that makes it impossible to identify the citizen ('photograph' hereafter). The requirements for the technical design of the photograph are set out in a decree of the Ministry of the Interior.

The explanatory report for the law comments on this change as follows:

Contrary to the current legislation, an exception concerning head covering is included in the provision on the presentation of a photograph on the identity card. In cases where this is usual, that is, for religious and health reasons, the citizen is allowed to have a head covering in the photograph.

An implementing decree of the Ministry of the Interior was issued in $2000 .{ }^{31}$ In $\S 6$, it provides detailed requirements for the design of the photograph, such as the possibility of using black and white or colour photography, the exact dimensions of the photograph, and the design of its background. These requirements are repeated in the 2004 Decree, $^{32}$ which also discusses the possible digital processing of photography. In addition, it distinguishes between two versions of the identity card - with and without machine-readable data. A new decree from $2011^{33}$ envisages the acquisition of a digital photograph directly at the office where the application for an identity card was submitted, although it leaves open the possibility of sending a digital photograph from the photographer. It orders that a digital photograph be entered into the Ministry of the Interior database and envisages placing an electronic chip on the back of the card.

The latest legal regulation, the Identity Card Act, was issued in $2021^{34} \mathrm{This}$ act requires that the identity card include machine-readable biometric data - facial images and handprints taken under Regulation (EU) 2019/1157 of the European Parliament and of the Council - and therefore eliminates the possibility of issuing an identity card without machine-readable data (while introducing a temporary identity card instead). It also enables the issuance of an identity card to persons under the age of 15 (eventually without fingerprinting) and liberalises the administration of issuing identity cards. The administrative office was newly determined as the sole venue for acquiring a digital photograph. The appearance of the person to whom the identity card is issued is described on the

31 | Decree of the Ministry of Interior no. 177/2000 Sb., implementing the act on identity cards and the act on travel documents.

32 | Decree of the Ministry of Interior no. 642/2004 Sb., implementing the act on identity cards and the act on travel documents.

33 | Decree of the Ministry of Interior no. 400/2011 Sb., implementing the act on identity cards and the act on travel documents.

34 | Act no. 269/2021 Sb. on identity cards. 
card in two ways: directly on the data page (the photo on the identity card) and stored in a data carrier containing biometric data. The execution of the photograph is specified in detail by a decree of the Ministry of the Interior issued in the same year, ${ }^{35}$ in which $\S 20$ (3) stipulates the possibility of an exception:

The person to whom an identity card is issued may take the form of a head covering, which may not cover the face in such a way as to make it impossible to identify the person if it is wearing it for medical or religious reasons.

\section{| 3.2. Overview of legal regulation regarding passports}

The legal regulation of passports also began in the interwar period (during the First Czechoslovak Republic). Czechoslovakia began regulating the use and issuance of passports soon after its inception, first via provisional government regulations from $1918^{36}$ and $1919,{ }^{37}$ and subsequently by the Passport Act of $1928 .{ }^{38}$ These norms also followed Imperial Regulation No. 31/1857 RGBl on the introduction of a new passport system, ${ }^{39}$ and its implementation instruction No. 32/1857 RGBl. To cross the Czechoslovak border, every citizen had to have a Czechoslovak passport, and every foreigner had to have a passport corresponding to the requirements set out in this act. The act did not address the execution of the photograph.

Further regulation occurred during the communist regime. The Passport Act was issued in $1949,{ }^{40}$ with implementing regulations for it passed in $1951,{ }^{41} 1953,{ }^{42}$ and $1959 .{ }^{43}$ Another law on travel documents was issued in $1965^{44}$ along with an implementing decree ${ }^{45}$ and the next decree was passed in $1970 .{ }^{46}$ In addition to a passport, an exit permit is often needed, which effectively limits the use of passports. ${ }^{47}$ None of these norms specified detailed regulations for the photograph; in practice, the regulations for identity cards were used for passports, which is why photographs made this way were called 'documentary photographs'.

35 | Decree of the Ministry of the Interior no. 281/2021 Sb. on the implementation of the Act on Identity Cards and certain provisions of the Act on Travel Documents and the Act on Basic Registers.

36 | Government regulation no. 87/1918 Sb. z. a n. on the issuance of passports.

37 | Order of the Minister of Finance in agreement with the Minister of the Interior, the Minister of Industry, Trade and Trades, and the Minister of Foreign Affairs no. 46/1919 Sb. z. a n., for the implementation of the Decree of 22 December 1918, no. 87 Sb. z. a n., on the issuance of passports.

38 | Act no. 55/1928 Sb. z. a n., on passports.

39 | Kaiserliche Verordnung Nr. 31/1857 RBl., wirksam für alle Kronländer, über die Einführung eines neuen Paßsystemes.

40 | Act no. 53/1949 Sb. z. a n., on passports.

41 | Decree of the Ministry of Foreign Affairs No. 2/1952 Ú.1., which issues more detailed regulations on the Passport Act.

42 | Decree of the Ministry of Foreign Affairs no. 69/1953 Ú.l., on the exchange of passports and their registration.

43 | Decree of the Ministry of Foreign Affairs no. 100/1959 Ú.l., on the issuance of passports.

44 | Act no. 63/1965 Sb., on travel documents.

45 | Decree of the Ministry of the Interior and the Ministry of Foreign Affairs no. 64/1965 Sb., which issues implementing regulations for the Act on Travel Documents.

46 | Decree of the Ministry of the Interior and the Ministry of Foreign Affairs no. 44/1970 Sb., which issues implementing regulations for the Act on Travel Documents.

47 | Dealing with the travel clause would be too burdensome for this article. 
Damián NĚMEC
Legal Regulation of Religious Clothing in the Public Sphere in the Czech Republic

The Travel Document Act, which respects the right to travel abroad freely and to return home ${ }^{48}$ was issued during the post-communist Czechoslovak Federation in 1991, along with its implementing decree. ${ }^{49}$ Another significant amendment was the Travel Document Act of 1999, ${ }^{50}$ issued together with the Act on Identity Cards and containing identical principles. This act also stipulates an exception to the requirement for an uncovered head:

For religious or medical reasons, a head covering photograph may be submitted with the application for a travel document; this cover must not cover the facial part in a way which would make identification impossible.

Since the issuance of this act, more detailed instructions have been laid down in decrees regulating both identity cards and travel documents, including the latest Decree no. $281 / 2021 \mathrm{Sb}$.

\section{| 3.3. Evaluation of requirements for photographs in personal documents in terms of the use of religious clothing}

There were no problems with wearing a head covering for religious reasons in identity document photos in the first decades after the establishment of Czechoslovakia in 1948. This was mainly due to the Austrian tradition, where religion was a common part of public life.

This gradually changed after the Communist Party of Czechoslovakia took power in February 1948. By no means was there a sudden turning point on the issue of personal documents because the communist regime sought an agreement with churches, especially the Roman Catholic Church, at least until mid-1949. ${ }^{51}$

After 1949, the regime sought to push visible manifestations of religion, including clothing, out of public life. At the same time, the religious situation was simplified. The Jewish population had been liquidated almost entirely during World War II. There were very few Muslims in Czech lands, and the legal status of Muslims in Czechoslovakia was problematic after World War II. ${ }^{52}$ Catholic priests increasingly wore civilian clothing (usually a suit with a clerical colar) instead of a clerical garb. When they lost state approval to perform clerical work, the state called them 'former priests'. They had to work in civilian jobs, and many were drafted into military service or imprisoned. Men in religious orders were expelled from their monasteries from April to May 1950, were interned, or were drafted into military service for several years. Upon their return, they usually worked in civilian occupations and wore civilian clothes. Therefore, their photographs on identity

48 | Act no. 216/1991 Sb. on travel documents and travelling abroad.

49 | Government regulation no. 512/1991 Sb. implementing the Act no. 216/1991 Sb. on travel documents and travelling abroad.

50 | Act no. 329/1999 Sb. on travel documents and on the amendment of Act no. 283/1991 Sb. on the Police of the Czech Republic (Act on Travel Documents).

51 I I add a personal memory to illustrate. My mother remembered that, in 1946 - before the first parliamentary elections after World War II - communist Jiří Pelikán performed in their village under the slogan 'Jesus Christ, the first communist'.

52 | After World War II, Brikcius, the leading representative of Czechoslovak (or rather Czech) Muslims, was arrested and sentenced to a long prison term for anti-Jewish activities during World War II; See Němec and Hesová, 2021, p. 35. 
cards and travel documents (if they received them at all) were taken with them wearing civilian clothes.

At that time, head covering for religious reasons was an issue only for Christian women. Although Christians were under strong pressure, including via the closing of most monasteries in the autumn of 1950 and subsequent internment, the vast majority of them did not put aside their religious clothing, even when in difficult working conditions in factories.

The exchange of identity cards for newer ones also took place over a period of years. It is therefore not surprising that religious women continued to use photographs of themselves in religious attire, including veils, in personal documents. Although the veils were often very distinctive in shape, they never covered their faces or made it impossible to identify them.

The use of photographs taken in religious clothing for personal documents has persisted even though it has been explicitly ordered since 1978 that photographs should be taken in civilian clothing and without a head covering. This can be attributed to several reasons.

First, the requirement for civilian clothing is ambiguous. The Czech legal system lacks a definition of 'civilian clothing'. The term is therefore understood to refer to clothing used in ordinary social relations, in contrast to domestic, work, or sport clothing. For religious women, religious clothing is the usual clothing they use in daily social relations.

Second, the degree of social sustainability is an important issue. The will of religious women could not be broken in the 1950s, when the regime used very harsh coercive means, and it was no longer socially acceptable in the 1970s to force nuns to take the photographs used in personal documents without wearing a religious veil. The condition was, however, that these women had to have been officially religious before the regime was founded (i.e. had to have entered their orders or congregations before 1950 or during the period of partial liberation of 1968-1970). Secretly received religious women wore civilian clothes and were photographed in them for personal documents.

Moreover, using photographs of women wearing religious attire in personal documents had certain advantages for the totalitarian regime. It made it easy to identify them during police checks if they operated outside the convent in civilian attire, which was done for conspiratorial reasons, especially when working with young people. The totalitarian regime was a police state, and arguments made by the police, both public and (above all) secret, carried very great weight with it. Paradoxically, it was precisely for these conspiratorial reasons that religious women were sometimes photographed in civilian clothes for their personal documents in the 1980 s. $^{53}$

Since the fall of the communist regime in 1990, photographs taken in religious clothing have been used in personal documents for religious women, and sometimes for men (usually without a head covering, with the exception of Orthodox monks). With the easing of religious oppression and increased population migration in the Czech Republic, other religions have emerged that emphasise religious clothing, including Islam, which traditionally requires headdress for women. Under the Charter of Fundamental Rights and Freedoms, respect for this practice is reflected in the laws on identity cards and travel

53 | Thus, the sisters of the Congregation of the Sisters of Mercy of St. Charles Borromeo recall that their then-revered General Superior, the Venerable Vojtěcha Hasmandová, ordered some sisters (usually younger, admitted between 1968 and 1970) to have a photograph taken in civilian clothes for their personal documents. 
Damián NĚMEC
Legal Regulation of Religious Clothing in the Public Sphere in the Czech Republic 101

documents enacted in 1999, which remained after the legal regulation of 2021. These laws apply to all religious groups, not just state-registered churches and religious communities, which can lead to bizarre consequences. ${ }^{54}$

\section{| 3.4. Reflections and suggestions de lege ferenda}

Although the current legislation largely guarantees the exercise of religious freedom, several questions remain. It is clear that respect for public expressions of religious freedom applies to all religions, not just those registered by the state as churches and religious communities according to Act no. 3/2002 Sb.

Because official photographs for personal documents can be acquired only from officials at municipal or city offices, a conflict may occur between the view of an official and that of a resident. A visual model for correct identification photographs is provided by the Ministry of the Interior, but it is not legally binding; it merely explains the legal provisions. Therefore, it is an official interpretation, but has no legal force. Thus, a binding legal document (i.e. a by-law) should be issued. Such a regulation should probably be issued via a decree of the Ministry of the Interior, published in the Collection of Laws and Regulations (and therefore easily accessible to the public), rather than merely a methodological instruction published in the Ministry of the Interior Bulletin.

\section{Regulation regarding the right of assembly}

\subsection{Overview of legal regulation regarding the right of assembly}

The right to associate was enshrined in the Czechoslovak constitutions of 1920 , 1948, and 1960, but not absolutely. The Czechoslovak Constitution of 1920 provided in $\S$ 113 (3) the possibility of restricting this freedom by law and defined the objectives of the restriction through a demonstrative list. The first communist constitution from year no. 150/1948 Sb. contains in $\S 23$ (1) the following restrictions: 'provided that this does not endanger the people's democratic establishment or public peace and order'. In addition, the communist constitution no. 100/1960 Sb., Article 28 guarantees this right in accordance with the interests of the working people'. The current constitutional enshrinement is contained in the 1991 Charter of Fundamental Rights and Freedoms. ${ }^{55}$

The implementation of this right is regulated by laws and by-laws. After the establishment of Czechoslovakia, the 1867 Austrian law on the right of assembly continued to be applied. ${ }^{56}$ This law did not regulate the clothing worn by participants in assemblies. The law was not replaced until $1951,{ }^{57}$ with $\S 6$ (1) effectively restricting the exercise of the right of assembly:

54 | For example, pastafarians could ask to be photographed with a colander on their heads, and, legally, they would have a good chance of success.

55 | Cf. above chapter 2.

56 | Gesetz Nr. 135/1867 RGBl., über das Versammlungsrecht.

57 | Act no. 68/1951 Sb. on voluntary organisations and assemblies. 
In accordance with the interests of the working people, citizens are guaranteed the exercise of the right of assembly, provided that it does not menace the people's democratic establishment or public peace and order.

The implementing decree issued in the same year ${ }^{58}$ contains no regulations regarding the attire of participants in an assembly.

The most recent regulation is given by the 1990 Act on the Right of Assembly, which is very liberal. Later amendments were made mainly because of the need to respond to the abuse of this right, especially through acts of violence, and to remedy the significant shortcomings of the law. Therefore, it was first amended in $2002,{ }^{59}$ adding to $\S 7$ a new paragraph 4:

The participants of the assembly may not have their faces covered in a way that makes it difficult or impossible to identify them, if the intervention of the Police of the Czech Republic is carried out against the assembly.

The provision of paragraph 4 was tightened in $2008^{60}$ to read as follows:

The participants of the assembly may not have their faces covered in a way that makes it difficult or impossible to identify them.

The latest amendment, introduced by the 2021 Pandemic Act, ${ }^{61}$ added this paragraph:

The participants of the assembly may not have their faces covered in a way that makes it difficult or impossible to identify them, if the authority or the Police of the Czech Republic issues such an instruction, if the peaceful course of the assembly is disrupted or endangered.

The latest amendment was not included in the government bill, and is thus not commented on in the explanatory report for the law. It appeared in a comprehensive amendment (actually, a new wording of the bill) submitted by Minister of the Interior Jan Hamáček as a deputy on the basis of an agreement brokered with difficulty among the representatives of all political parties in the Czech Republic's Chamber of Deputies (its lower house of parliament). This proposal was presented as a sign of goodwill on behalf of the governing coalition. This amendment was based on the case law of the Supreme Administrative Court, which had ruled that the requirement to leave the face uncovered (including in traditional masquerades and similar parades) was adequate.

58 | Decree of the Minister of the Interior no. 320/1951 Ú.l. on voluntary organizations and assemblies 59 | Act no. 259/2002 Sb., amending Act no. 84/1990 Sb., on the right of assembly, as amended by Act no. 175/1990 Sb., and certain other acts.

60 | Act no. 274/2008 Sb. amending certain acts in connection with the adoption of the Act on the Police of the Czech Republic.

61 | Act no. 94/2021 Sb. on emergency measures in the event of an epidemic of COVID-19 and amending some related acts. This law makes it possible to take certain epidemiological measures without declaring a state of emergency. 
The Ministry of the Interior issued an explanatory opinion regarding masking during an assembly on its website, ${ }^{62}$ summarising the reasons for the legal regulation and the rules for its application. However, as is common for ministries, it is not dated, and it lacks a reference number and the name of the person who signed it. In addition, it cites the wording of the law before the last amendment, which is not only a material error but also reduces the credibility of this opinion (and of the ministry itself).

\subsection{Evaluation of requirements regarding religious clothing for assembly participants}

The regulation given by the Act on the Right of Assembly no. 84/1990 Sb. in its original version imposes no restriction on the use of religious clothing. After the law's tightening, which was criticised by the Supreme Administrative Court, the last amendment to the Act in 2021 forbids participants in an assembly to cover their faces in a way that makes it difficult or impossible to identify them, but only during an interaction with Czech police. The 2021 amendment clarifies this ban by stating that it applies only to cases in which the peaceful conduct of the assembly is being disrupted.

It can therefore be stated that the regulation of the right of assembly in the Czech Republic interferes with the right to express one's religious beliefs by wearing religious clothing to only a minimal extent - marginally, in fact.

\section{| 4.3. Reflections and suggestions de lege ferenda}

The current restriction on facial masking during a public meeting, which is the result of judicial review, imposes a very narrowly defined obligation on meeting participants, and is also subject to a clear definition of the authority of Czech Republic police. It seems unnecessary to lay down any further legal or by-law definition.

\section{Regulation of wearing religious clothes in schools}

\subsection{Legal basis for wearing religious clothes in schools}

The wearing of religious clothing in schools has never been regulated by law in the Czech Republic. The traditional tools for regulating individual schools are schools' internal regulations, which fall under the Education Act. ${ }^{63}$ According to $\S 30$ of the act, these regulations are issued by the school director. The school rules regulate the following:

a) details on the exercise of the rights and obligations of children, pupils, students, and their legal representatives in the school or school facility and details on the rules of mutual relations with staff in the school or school facility

b) working and internal regime of the school or school facility,

62 | Approach of the Ministry of the Interior on the issue of masking during the assembly; available at: https://www.mvcr.cz/clanek/stanovisko-ministerstva-vnitra-k-problematice-maskovanibehem-shromazdeni.aspx (Accessed 25.08.2021).

63 | Act no. 561/2004 Sb., on pre-school, primary, secondary, higher vocational and other education (School Act). 
c) conditions for ensuring the safety and health protection of children, pupils, or students and their protection against socially pathological phenomena and against manifestations of discrimination, hostility, or violence

d) conditions for the treatment of school or school property by children, pupils, and students

At the same time, under $\S 29$ of the act, the school is obliged to ensure the safety and health protection of children, pupils, and students. School rules can in certain circumstances be interpreted as a rule of law, as required by Article 16 (4) of the Charter of Fundamental Rights and Freedoms. However, this applies only in situations where the school rules restrict freedom of the expression of religion to fulfil obligations imposed on the school by the Education Act. It is therefore primarily a matter of ensuring the safety, protection, and health of pupils. Thus, the school may apply such restrictions to pupils' clothing at school, which will prevent threats to their health and safety. ${ }^{64}$

In addition to the constitutionally guaranteed rights and freedoms set out in the Charter of Fundamental Rights and Freedoms, the Anti-discrimination Act has important provisions. ${ }^{65}$ In $\S 2$ (3), direct discrimination is defined as follows:

(3) Direct discrimination means such conduct, including the omission of one person being treated less favourably than another, has been or would be treated in a comparable situation, on grounds of race, ethnic origin, nationality, sex, sexual orientation, age, disability, religion, belief, or worldview, as well as in legal relations in which the directly applicable regulation of the European Union in the field of free movement of workers applies, also on the grounds of nationality.

In $\S 3$ (1) it defines indirect discrimination as follows:

(1) Indirect discrimination means such an act or omission where, based on a seemingly neutral provision, criterion, or practice, a person is disadvantaged compared to others for one of the reasons stated in $\S 2$ (3). It is not indirect discrimination if that provision, criterion, or practice is objectively justified by a legitimate aim, and the means of achieving it are proportionate and necessary.

On the other hand, the law stipulates that there may be no discrimination but merely a difference in treatment between individuals. The area of freedom of conscience is covered by the provisions in $\S 6$ (3):

(3) Discrimination is not a difference in treatment in matters of the right to employment, access to employment or occupation, in matters of employment, service or other dependent activity, if there is a factual reason to do so due to the nature of the work or activity and the requirements applied. Discrimination on grounds of sex does not consist in a difference in treatment as regards access to or training for employment or occupation, provided that the factual reason for doing so is the nature of the work or activity performed and the requirements applied are proportionate to that nature.

64 | Kohl (2021), p. 30.

65 | Act no. 198/2009 Sb. on equal treatment and legal means of protection against discrimination and on amendments to certain acts (Anti-Discrimination Act). 


\section{| 5.2. Secondary medical school student versus the school: the wearing of hijab}

The regulations governing the wearing of religious symbols are strongly affected by a court case brought by a secondary medical school student against the school.

In September 2013, two girls - both of whom had received asylum in the Czech Republic - wanted to attend a secondary medical school in Prague 10. Both girls were Muslim, one came from Somalia and the other from Afghanistan. Attempts to study ended in conflict. The Somali girl signed a declaration that she was dropping out of school on her first day after a conflict with the schoolmistress, and the Afghan girl left after two months of classes. Both argued that their religious rights had been violated because, according to the school rules, they were not allowed to cover their heads with a hijab during class, including classes on theoretical subjects, which the schoolmistress required. It should be noted that both students should have agreed to take off their hijab during practical classes in healthcare facilities.

In November 2013, the Somali girl lodged a complaint with the ombudswoman, who in July 2014 issued an opinion stating that the school's conduct was discriminatory. ${ }^{66}$ The same girl filed a lawsuit against the school in February 2016, in which she demanded an apology for the allegedly discriminatory conduct and payment of 60,000 Czech crowns (approximately 2,400 euros) in non-pecuniary damages.

In response to the Somali student's case, the Ministry of Education issued a communication in 2014 urging school directors to be very careful when setting dress codes, especially as regards head covering, in light of the right to freely express a religion or belief. ${ }^{67}$ The wording of this communication is general and recommends that directors be empowered to grant exemptions to school guidelines, primarily for religious reasons. The content of the communication could thus be summed up in the popular saying 'less often means more'.

In January 2017, the court of the first instance - the district court for Prague 10 accepted the opinion of the schoolmistress that there was no discrimination against the student. The student did not deliver the legally required documents - a permit to stay in the Czech Republic and a hand-signed enrolment form for the school - on the day she started school. The schoolmistress therefore claimed that the applicant had not become a student at the school at all and that, consequently, refusing her entry was not discriminatory. Therefore, the court did not address the question of whether the school rules showed signs of direct or indirect discrimination. ${ }^{68}$

The applicant appealed to the court of the second instance, the Municipal Court in Prague. On September 19, 2017, the Court of Appeal upheld the decision of the lower court, dismissing the action. It also addressed the potential indirect discrimination against the applicant by the school, based on school rules. The court stated that there was no discrimination because the provisions of the school rules are uniform for all students and fully correspond to the secular nature of public education in the Czech Republic. The court described the Ombudswoman's report as contradictory and erroneous in the context of

66 | Public Defender of Rights. Inquiry report on the ban on wearing headgear in a secondary medical school, file number 173/2013/DIS/EN, of 2 July 2014.

67 | Ministry of Education. Communication, 'The right to freely express one's religion or belief in the context of the rules of theoretical and practical teaching in schools and school facilities', File no. ČŠIG-3601/14-G21, of October 6, 2014; it should be noted that this document has a date and a reference number, although it is not known who signed it.

68 | Judgment of the District Court for Prague 10, file number 17 C 61/2016-172, of 27 January 2017. 
other facts. At the same time, however, it also stated that there is no unanimous view on the wearing of religious symbols, especially in the European Union. ${ }^{69}$

The plaintiff then lodged an extraordinary appeal: an appeal for cassation to the Supreme Court of the Czech Republic. In its judgment of November 27, 2019, the Supreme Court reversed the prior rulings. Unlike previous courts, it declared it irrelevant whether the plaintiff had been a student or not. It addressed the possibility of discrimination by the school and concluded that the school had indirectly discriminated against the applicant because the school rules prevented the legitimate expression of religious freedom (i.e. the wearing of the hijab for Muslim women). It thus agreed with the 2014 opinion of the Ombudswoman. It therefore overturned both previous judgments and returned the case to the court of first instance; lower courts are bound by the legal opinion of the Supreme Court.70

However, the District Court for Prague 10 did not begin to hear the merits of the case because the applicant withdrew the action on April 24, 2020. She argued that almost seven years had elapsed since the events in question and, in view of the years of litigation ahead of her, no apology or symbolic compensation would provide satisfaction; thus, she considered the Supreme Court's decision satisfactory. As a consequence of this action, the applicant was exposed to further trouble (e.g. threats, disgraceful claims in the media, difficulty finding housing and employment), and she wanted to find peace of mind at work and a normal life without having to deal with a seven-year-old event. Therefore, the court decided to stop the proceedings. ${ }^{71}$

However, the school did not agree with the withdrawal and demanded that a decision be made on the merits of the case. It therefore lodged an appeal because the school had a serious moral interest in the decision (given its impact on the school's reputation and on the personal rights of the schoolmistress). The school announced as follows: '[it] absolutely does not agree with the judgment of the Supreme Court, it considers it to be factually and legally incorrect and argumentatively erroneous'. The Municipal Court upheld the appeal and finally stopped the proceedings on January 27, 2021. An appeal to the Supreme Court can be made as an extraordinary remedy only if the procedure of the court of appeal was contrary to legal norms. ${ }^{72}$ The school wants to continue proceedings with the student over the hijab. It therefore appealed to the Supreme Court in April 2021, ${ }^{33}$ but the outcome of the proceedings is uncertain.

\subsection{Evaluation of the case in terms of the use of religious clothing}

The case law of Czech courts on discrimination against Muslim women seeking to wear the hijab in theoretical classes is clearly inconsistent. The only legally binding case law is the decision of the Supreme Court, which is, however, still a unique case that stands

69 | Judgment of the Municipal Court in Prague, file number 12 Co 130/2017 - 228, of 19 September 2017.

70 | Judgment of the Supreme Court of the Czech Republic, file number 25 Cdo 348/2019-311, of 27 November 2019.

71 I Judgment of the District Court for Prague 10, file number 17 C 61/2016-350, of 20 July 2020.

72 I Judgment of the Municipal Court in Prague, file number 12 Co 304/2020 - 375, of 27 January 2021.

73 | Škola chce pokračovat v soudním sporu se studentkou o hidžáb. Obrátila se na Nejvyšší soud [The school wants to continue a lawsuit with a student over the hijab. It turned to the Supreme Court]. Available at: https://ct24.ceskatelevize.cz/domaci/3298073-skola-chce-pokracovat-v-soudnimsporu-se-studentkou-o-hidzab-obratila-se-na-nejvyssi (Accessed 26.08.2021). 
in clear contradiction with the decisions of lower general courts. The school may have opposed the withdrawal of proceedings in order to obtain a different opinion from the Supreme Court, or to present the case before the Constitutional Court of the Czech Republic, which is competent to rule on intrastate constitutionality, including on human rights. The matter may yet be submitted to the European Court of Human Rights.

In addition, the issue was strongly politicised. First, the case attracted very significant media coverage. Second, all court proceedings were accompanied by petitions and demonstrations, mostly in support of the position taken by the school and schoolmistress. Third, the President of the Czech Republic, Miloš Zeman, inserted himself into the case by awarding the schoolmistress the Medal for Merit of the First Degree and calling her 'a brave woman in the fight against an intolerant ideology' in October 2018. ${ }^{74}$ This was inappropriate given the ongoing proceedings before the Supreme Court, which finally ruled against the legality of the conduct of the school and its schoolmistress. Fourth, the schoolmistress also politicised the case by running for the Senate of the Czech Republic (its upper chamber) in 2021. Her campaign emphasised a consistent position on immigrants - that they must adapt to the legal and cultural customs of the host country. However, the schoolmistress finished ninth out of 11 candidates in the first round of the election, winning only $3.64 \%$ of the vote. ${ }^{75}$ This case also led to controversy and debate in the media, especially on social networks.

\section{| 5.4. Reflections and suggestions regarding de lege ferenda}

The legal situation in the Czech Republic is somewhat unusual. On the one hand, the concrete case law of the Supreme Court is legally binding only in a concrete case, but no binding case law has emerged. On the other hand, this case law can be invoked by any lower ordinary court.

The Ministry of Education responded to this situation even before the Supreme Court rendered its decision via its communication on the right to freedom of expression in schools. However, this communication does not have the nature of a generally binding regulation. Therefore, the Ministry should issue a generally binding regulation based on an evaluation of national legislation and case law and of the case law of judicial institutions of the European Union (European Court of Human Rights and European Court of Justice), preferably through a ministerial decree. Such a decree should regulate the wearing of religious symbols and clothing, particularly headgear, in classes dealing with theory.

\section{Conclusion}

The constitutional right to express one's religion via religious clothing is widely guaranteed by the Charter of Fundamental Rights and Freedoms, which is part of the Czech Republic's constitutional order. The Charter requires that restrictions on the exercise of these rights be provided for by law - namely, in cases where they are necessary in a

74 | Pražský hrad, Prezident ČR. Prezident republiky udělil státní vyznamenání, 28. ř́ijna 2018. Available at: https://www.hrad.cz/cs/pro-media/tiskove-zpravy/aktualni-tiskove-zpravy/prezidentrepubliky-udelil-statni-vyznamenani-8-14366 (Accessed 25.05.2021).

75 | volby.cz. Volby do Senátu Parlamentu ČR konané dne 2.10. - 3.10.2020. Available at: https://www. czso.cz/csu/czso/volby-do-senatu-parlamentu-cr-2020 (Accessed 25.05.2021). 
democratic society for the protection of public safety and order, health and morals, or the rights and freedoms of others.

Regarding personal documents, a key question is the legal requirements that apply to the form of the holder (the photograph). Although the legal regulation of identity documents is very extensive and has its roots in the Austro-Hungarian period, the requirements for photography were legally defined only after the communist regime took power in 1948. Although it was ordered that citizens must be depicted without a head covering, religious veils continued to be tolerated. Since 1999, the use of headgear has been expressly permitted for religious or medical reasons.

The wearing of religious clothing by participants in public assemblies has not been legally limited. A ban on face coverings has existed since 2002. Since 2021, this ban has been very narrow, and has applied only in cases where the Czech police are investigating a possible violation of a peaceful assembly.

Wearing religious clothing in schools was practically banned throughout the communist period (1948-1989) without a legal basis. The only exception applied to clergy involved in religious education, but they usually wore civilian clothing. Even after 1989, there was no legal regulation, and it was left up to school directors to outline details via school regulations. This issue was strongly affected by a Muslim student's lawsuit against a medical secondary school in 2013. Although a final court decision has not yet been reached, the Supreme Court ruled that the general ban on wearing headdress during classes of theoretical instruction constituted indirect discrimination. In April 2021, the school appealed the suspension of court proceedings to the Supreme Court, while the Ministry of Education had announced in 2014 that school regulations should allow for the exceptional wearing of a head covering for religious or health reasons.

It is therefore clear that the wearing of religious clothing is regulated very loosely in the Czech Republic and is restricted to a very few specific areas. Current legal regulations should be clarified, particularly regarding the competence of official bodies concerning photographs used in personal documents and the right of schools to regulate the wearing of headgear in class, especially in theoretical classes.

\section{Biography}

Born in 1960 in Boskovice (Czech Republic, Moravia), maternal tongue Czech.

Dominican since 1986, ordained priests in 1991, 1998-2002 provincial of the Czech Dominican Province.

Professor at the Palacký University of Olomouc, teaching canon law and religion law at the Faculty of Theology, and at the Faculty of Philosophy. Research worker at the Faculty of Law at the University of Trnava (Slovak Republic).

Translator of several official documents of the Catholic Church in Czech. Translator of liturgical texts of the Catholic Church into the Czech Republic.

Member of the Canon Law Society (Prague) and its Institute of Religion Law. Member of Consociatio Internationalis Studio Iuris Canonici Promovendo (Roma), Société International de Droit Canonique et de Législations Religieuses Comparées (Paris), International Consortium for Law and Religion Studies (ICLARS) (Milano), and the European Society for History of Law (Brno). 


\section{Bibliography}

Act of the National Committee of Czechoslovakia no. 11/1918 Sb. z. a n., on the establishment of an independent Czechoslovak state.

| Act no. 55/1928 Sb.z. a n., on passports.

I Act no. 95/1948 Sb., on the basic regulation of unified education (School Act).

| Act no. 198/1948 Sb., on identity cards.

| Act no. 53/1949 Sb.z. a n., on passports.

Act no. 218/1949 Sb., on economic indemnity of churches and religious communities by the state (Act on Churches and Religious Communities).

| Act no. 68/1951 Sb., on voluntary organisations and assemblies.

| Act no. 75/1957 Sb., on identity cards.

| Act no. 63/1965 Sb., on travel documents.

Act no. 198/1993 Sb., on the illegality of the communist regime and on resistance against it

I Act no. 84/1990 Sb., on the right of assembly.

| Act no. 216/1991 Sb., on travel documents and travelling abroad.

Act no. 308/1991 Sb., on freedom of religious faith and the status of churches and religious communities (Act on Churches and Religious Communities).

| Act no. 328/1999 Sb., on identity cards.

Act no. 329/1999 Sb., on travel documents and on the amendment of Act no. 283/1991 Sb., on the Police of the Czech Republic (Act on Travel Documents).

Act no. 3/2002 Sb., on freedom of religion and the status of churches and religious societies and on the amendment of certain laws (Act on Churches and Religious Communities).

Act no. 259/2002 Sb., amending Act no. 84/1990 Sb., on the right of assembly, as amended by Act no. 175/1990 Sb., and certain other acts.

Act no. 561/2004 Sb., on pre-school, primary, secondary, higher vocational and other education (School Act).

Act no. 274/2008 Sb., amending certain acts in connection with the adoption of the Act on the Police of the Czech Republic.

Act no. 94/2021 Sb., on emergency measures in the event of an epidemic of COVID-19 and amending some related acts.

| Act no. 269/2021 Sb., on identity cards.

Approach of the Ministry of the Interior on the issue of masking during the assembly. Available at: https://www.mvcr.cz/clanek/stanovisko-ministerstva-vnitra-kproblematice-maskovani-behem-shromazdeni.aspx (Accessed: 25.08.2021). 
Act no. 198/2009 Sb., on equal treatment and legal means of protection against discrimination and on amendments to certain acts (Anti-Discrimination Act).

Constitutional act no.121/1920 Sb. z. a n., introducing the Constitutional Charter of the Czechoslovak Republic.

| Constitutional act no. 150/1948 Sb., Constitution of the Czechoslovak Republic.

| Constitutional act no.100/1960 Sb., Constitution of the Czechoslovak Socialist Republic.

Constitutional act no. 23/1991 Sb., which introduces the Charter of Fundamental Rights and Freedoms as a constitutional law of the Federal Assembly of the Czech and Slovak Federal Republic.

| Constitutional act no.1/1993 Sb., Constitution of the Czech Republic.

Constitutional Decree of the President of the Republic no. 11/1944 Úř. věst. čsl., on the restoration of legal order.

Decree of the Minister of the Interior no. 320/1951 Ú.l., on voluntary organizations and assemblies.

Decree of the Federal Ministry of the Interior no. 135/1978 Sb., which issues more detailed regulations on identity cards.

Decree of the Federal Ministry of the Interior no. 119/1984 Sb., which issues more detailed regulations on identity cards.

Decree of the Minister of the Interior no. 338/1920 Sb. z. a n., on when the Order of the Government of the Czechoslovak Republic of 8 August 1919, no. 481 Sb. z. a n., on general civil identification cards, comes into force.

Decree of the Ministry of Foreign Affairs No. 2/1952 Ú.l., which issues more detailed regulations to the Passport Act.

Decree of the Ministry of Foreign Affairs no. 69/1953 Ú.l., on the exchange of passports and their registration.

| Decree of the Ministry of Foreign Affairs no.100/1959 Ú.l., on the issuance of passports. Decree of the Ministry of the Interior no. 2384/1948 Ú.l., which sets out the details of identity cards.

Decree of the Ministry of the Interior no. 5/1958 Ú.l., which issues more detailed regulations on identity cards.

Decree of the Ministry of the Interior and the Ministry of Foreign Affairs no. 64/1965 Sb., which issues implementing regulations to the Act on Travel Documents.

Decree of the Ministry of the Interior and the Ministry of Foreign Affairs no. 44/1970 Sb., which issues implementing regulations to the Act on Travel Documents.

Decree of the Ministry of the Interior no. 128/1993 Sb., which implements the act on identity cards.

Decree of the Ministry of Interior no. 177/2000 Sb., implementing the act on identity cards and the act on travel documents. 
Damián NĚMEC
Legal Regulation of Religious Clothing in the Public Sphere in the Czech Republic 111

Decree of the Ministry of Interior no. 642/2004 Sb., implementing the act on identity cards and the act on travel documents

Decree of the Ministry of Interior no. 400/2011 Sb., implementing the act on identity cards and the act on travel documents.

Decree of the Ministry of the Interior no. 281/2021 Sb., on the implementation of the Act on Identity Cards and certain provisions of the Act on Travel Documents and the Act on Basic Registers.

Decree of the Ministry of National Security no. 240/1953 Ú. 1., which issues more detailed regulations on identity cards.

| Gesetz Nr.135/1867 RGBl., über das Versammlungsrecht.

| Government regulation no. 87/1918 Sb. z. a n., on the issuance of passports.

Government regulation no. 31/1945 Sb. z. a n., which stipulates the end of the unfree period for the field of regulations on the restoration of legal order.

Government regulation no. 61/1953 Sb., on identity cards.

Government regulation no. 512/1991 Sb., implementing the Act no. 216/1991 Sb., on travel documents and travelling abroad.

Jäger, P. (2012a) 'Svoboda myšlení, svědomí a náboženského vyznání ['Freedom of Thought, Conscience and Religion'] in Wagnerová, E. et al. (eds.) Listina základních práv a svobod: komentár [Charter of Fundamental Rights and Freedoms: Commentary]. Praha: Wolters Kluwer.

Jäger, P. (2012b) 'Právo svobodně projevovat své náboženství a autonomie církví ['The Right to Freely Express One's Religion and the Autonomy of the Churches'] in Wagnerová, E. et al. (eds.) Listina základních práv a svobod: komentár [Charter of Fundamental Rights and Freedoms: Commentary]. Praha: Wolters Kluwer.

Judgment of the Constitutional Court of 27 November 2002 no. 4/2003 Sb. in the matter of a proposal to repeal act no. 3/2002 Sb., on freedom of religion and the status of Churches and religious Communities and to amend certain acts (Act on Churches and Religious Communities), or to repeal certain provisions of this Act.

Judgment of the District Court for Prague 10, file number 17 C 61/2016-172, of 27 January 2017.

Judgment of the District Court for Prague 10, file number 17 C 61/2016-350, of 20 July 2020.

Judgment of the Municipal Court in Prague, file number 12 Co 130/2017 - 228, of 19 September 2017.

Judgment of the Supreme Court of the Czech Republic, file number 25 Cdo 348/2019311, of 27 November 2019.

Kaiserliche Verordnung Nr. 31/1857 RBl., wirksam für alle Kronländer, über die Einführung eines neuen Paßsystemes. 
Kohl, J. (2021) Svoboda projevu náboženství na školách (Diplomová práce) [Freedom of Expression of Religion in Schools (Diploma thesis)] Univerzita Palackého, Právnická fakulta [Palacký University, Faculty of Law].

Ministry of Education. Communication, 'The right to freely express one's religion or belief in the context of the rules of theoretical and practical teaching in schools and school facilities', File no. ČŠIG-3601/14-G21, October 6, 2014.

Němec, D. \& Hesová, Z. (2021) Annotated Legal Documents on Islam in Europe: Czech Republic. Leiden: Brill.

Order of the Minister of Finance in agreement with the Minister of the Interior, the Minister of Industry, Trade and Trades, and the Minister of Foreign Affairs no. 46/1919 Sb. z. a n., for the implementation of the Decree of 22 December 1918, no. 87 Sb. z. a n., on the issuance of passports.

Pražský hrad, Prezident ČR [Prague Castle, President of the Czech Republic]. Prezident republiky udělil státní vyznamenání, 28. řijna 2018 [The President of the Republic awarded the state decoration on October 28, 2018]. Available at: https://www.hrad.cz/ cs/pro-media/tiskove-zpravy/aktualni-tiskove-zpravy/prezident-republiky-udelilstatni-vyznamenani-8-14366 (Accessed: 25.05.2021).

Public Defender of Rights. Inquiry report on the ban on wearing headgear in a secondary medical school, file number 173/2013/DIS/EN, of 2 July 2014.

Regulation of the Government of the Czechoslovak Republic no. 481/1919 Sb. z. a n., which introduces general citizenship cards.

Resolution of the Presidency of the Czech National Council no. 2/1993 Sb., on the promulgation of the Charter of Fundamental Rights and Freedoms as part of the constitutional order of the Czech Republic.

Říha, Z. (2013) Právní úprava elektronických identifikačních průkazů a cestovních dokladů $v$ ČR (Diplomová práce) [Legal Regulation of Electronic Identification Cards and Travel Documents in the Czech Republic (Diploma thesis)]. Brno: Masarykova univerzita.

Škola chce pokračovat v soudním sporu se studentkou o hidžáb. Obrátila se na Nejvyšší soud [The school wants to continue a lawsuit with a student over the hijab. It turned to the Supreme Court]. Available at: https://ct24.ceskatelevize.cz/domaci/3298073skola-chce-pokracovat-v-soudnim-sporu-se-studentkou-o-hidzab-obratila-se-nanejvyssi (Accessed: 26.08.2021).

Verordnung der Ministerien des Äußern, des Innern und des Handels Nr. 32/1857 RGBl., der obersten Polizeibehörde und des Armee-Ober-Commando, wirksam für alle Kronländer, womit neue paßpolizeiliche Vorschriften erlassen warden.

volby.cz. Volby do Senátu Parlamentu ČR konané dne 2.10. - 3.10.2020 [Elections to the Senate of the Parliament of the Czech Republic held on 2.10. - 3.10.2020]. Available at: https:// www.czso.cz/csu/czso/volby-do-senatu-parlamentu-cr-2020 (Accessed: 25.05.2021).

Všeobecné občanské legitimace [General citizenship cards]. Available at http:// www.scanzen.cz/dobove-dokumenty/prukazy/vseobecna-obcanska-legitimace (Accessed: 25.07.2021). 